\title{
Evaluasi Penerapan Manajemen Waktu Pada Proyek Pembangunan Ciputra School of Business Makassar
}

\author{
Bona Eirene Mangape ${ }^{* 1}$, Josefine Ernestine Latupeirissa ${ }^{* 2}$, Lintje Tammu Tangdialla' ${ }^{3}$ \\ *1 Mahasiswa Program Studi Teknik Sipil, Universitas Kristen Indonesia Paulus Makassar, \\ Indonesia bonaeirene1999@gmail.com \\ *2,3 Dosen Program Studi Teknik Sipil, Universitas Kristen Indonesia Paulus Makassar, Indonesia ${ }^{2}$ \\ josefine_ernestine@yahoo.com *2² dan lintjettangdialla@gmail.com *3
}

Corresponding Author: lintjettangdialla@gmail.com

\begin{abstract}
Abstrak
Dunia konstruksi masih banyak ditemukan proyek yang pelaksanaannya tidak sesuai waktu yang ditentukan. Oleh karena itu perlu dilakukan evaluasi penerapan manajemen waktu pada proyek konstruksi gedung Ciputra School of Business yang mengalami keterlambatan pada beberapa sub bagian pekerjaan. Metode penelitian yang digunakan dalam penelitian ini yaitu metode analisis deskriptif. Dari hasil penelitian dapat diketahui bahwa dalam pelaksanaan proyek kurva-S digunakan sebagai time schedule dalam melakukan monitoring progress dan penjadwalan pekerjaan, kontraktor perlu melakukan pekerjaan secara paralel dengan metode percepatan fast tracking dan memberlakukan lembur agar target mingguan dan bulanan terpenuhi. Dari hasil analisis dapat disimpulkan bahwa pengendalian menggunakan kurva-S dimana baseline dilakukan pertiga bulan selama 1 tahun waktu pelaksanaan menunjukkan besaran deviasi progress pekerjaan pada tahap pertama $1.085 \%$, tahap kedua $1.324 \%$, tahap ketiga $-8,971 \%$, dan tahap keempat $-5,639 \%$
\end{abstract}

Kata kunci: Manajemen Waktu, Faktor-faktor keterlambatan, Ciputra School Of Business Makassar

\begin{abstract}
The construction world there are still many projects whose implementation does not match the specified time. Therefore, it is necessary to evaluate the application of time management in the construction project of the Ciputra School of Business building which experienced delays in several sub-sections of work. The research method used in this research is descriptive analysis method. From the results of the study, it can be seen that in the implementation of the $S$-curve project it is used as a time schedule in monitoring progress and scheduling work, contractors need to do work in parallel with the fast tracking acceleration method and apply overtime so that weekly and monthly targets are met. From the results of the analysis, it can be concluded that the control uses the S-curve where the baseline is carried out every three months for 1 year during the implementation period.
\end{abstract}

Keywords: Time Management, Factors of delay, Ciputra School Of Business Makassar

\section{PENDAHULUAN}

Dalam dunia konstruksi masih banyak ditemukan proyek-proyek pembangunan gedung yang pelaksanaannya tidak sesuai waktu yang ditentukan dikarenakan adanya faktor-faktor lain yang menyebabkan penyelesaian proyek tidak sesuai waktu yang dijadwalkan, maka diperlukan suatu analisa tentang pelaksanaan manajemen 
waktu proyek pembangunan gedung pada perusahaan kontraktor, sehingga dapat mengetahui kelemahan yang dilakukan selama ini, yang nantinya dapat membantu memberikan masukan bagi kontraktor. Proyek pembangunan Ciputra School of Business merupakan salah satu proyek yang sedang dibangun dalam Kawasan Center Point of Indonesia yang terletak di jalan Metro Tanjung Bunga Makassar. Pada proyek ini mengalami keterlambatan waktu pelaksanaan. Oleh karena itu perlu dilakukan analisa penerapan waktu ulang untuk memberikan masukkan kepada pihak kontraktor sehingga dapat mengantisipasi faktor-faktor yang menyebabkan keterlambatan waktu pelaksanaan.

Adapun penelitian ini bertujuan melakukan evaluasi penerapan manajemen waktu pada proyek konstruksi bangunan gedung Ciputra School of Business yang mengalami keterlambatan pada beberapa sub bagian pekerjaan.

Proyek adalah kombinasi sumber daya seperti tenaga kerja, bahan, peralatan, dan modal/biaya, yang digabungkan dalam suatu organisasi sementara untuk memperoleh suatu tujuan [1]. Proyek adalah serangkaian kegiatan yang saling terkait dengan titik awal, titik akhir, dan hasil tertentu. Biasanya proyek merupakan organisasi lintas fungsi oleh karena itu diperlukan berbagi keterampilan (skills) dari jenis pekerjaan dan organisasi yang berbeda [2].

Seperti yang telah diuraikan dari definisi di atas, ciri utama dari proyek adalah (1) Mempunyai sasaran dan tujuan yang dapat berupa suatu produk akhir (2) Proyek bersifat sementara, yaitu memiliki titik awal dan titik akhir yang jelas. (3) Dalam mencapai sasaran dan tujuan telah ditentukan biaya, waktu, dan mutu. (4) Intensitas dan jenis aktivitas menjadi berubah selama proyek berjalan dapat menyebabkan proyek mempunyai sifat nonrepetitive.

Dengan mengacu seluruh tahapan kegiatan proyek serta penggunaan sumber daya dan durasi penggunaan sumber daya maka standar kinerja waktu dapat ditentukan [1]. Dari seluruh data dan informasi yang telah didapatkan, dilaksanakan proses penjadwalan sehingga akan ada output berupa format-format laporan lengkap mengenai indikator progress waktu, sebagai berikut:

1. Barchart, dapat menampilkan jadwal proyek dan Informasi durasi kemudian dibandingkan dengan kemajuan yang sebenarnya untuk mengetahui apakah proyek tersebut mengalami keterlambatan.

2. Network Planning, Sebagai jaringan kerja untuk bermacam kegiatan, perencanaan jaringan serta menunjukkan kegiatan utama yang memerlukan pengawasan yang lebih teliti agar tidak menunda pelaksanaan proyek.

3. Kurva S, yang bermanfaat untuk mengendalikan kinerja waktu. Ini dapat dilihat dari bobot penyelesaian kumulatif pada kegiatan tersebut kemudian dibandingkan dengan keadaan aktual, sehingga dapat diketahui apakah proyek tidak dapat dikontrol atau terlambat dengan cara baseline pada periode tertentu dicantumkan.

4. Kurva Earned Value yang diperoleh sesuai dengan kemajuan proyek yang sebenarnya, dalam jangka waktu tertentu berdasarkan baseline yang telah ditentukan untuk periode waktu tertentu yang disesuaikan dengan kemajuan actual proyek.

Untuk mengelola proyek yang relatif besar, persoalan sumber daya merupakan subjek sekaligus objek. Oleh karena itu, keputusan tentang kualitas dan kuantitas harus dipertimbangkan dengan tepat. Jenis sumber daya adalah peralatan, moda tenaga kerja dan bahan [1]. Beberapa aspek yang wajib diperhatikan dalam membuat alokasi sumber daya proyek yaitu sebagai berikut (1) efesiensi dan aktivitas sumber daya, (2) produktivitas sumber daya, (3) kebutuhan Jumlah sumber daya pada proyek sesuai kebutuhan, (4) sumber daya yang akan digunakan sesuai situasi keuangan, (5) kemampuan dan kapasitas sumber daya

Alasan Keterlambatan dalam suatu proyek dibagi menjadi tiga yaitu: 
1. Excusable Non Compensable Delays, alasan paling umum keterlambatan yang mempengaruhi waktu pelaksanaan proyek adalah:

a. Force majeure, termasuk penyebabnya adalah Act of God, serta perang, huru hara, mogok kerja dan demonstrasi.

b. Act of God, Contohnya termasuk bencana alam termasuk banjir, badai, gempa bumi,, kebakaran, atau letusan gunung berapi..

c. Cuaca yang tidak mendukung dan melebihi batas kondisi normal merupakan faktor penyebab keterlambatan yang dapat menyebabkan (exercising delay).

2. Excusable Compensable Delays, ini disebabkan karena keterlambatan owner client, klaim dan perpanjangan waktu dan klaim atas keterlambatan tersebut hak kontraktor. Alasan yang termasuk dalam keterlambatan excusable compensable delay yaitu :

a. Keterlambatan persetujuan gambar manufaktur.

b. Terlambatnya pembayaran kepada pihak kontraktor.

c. Keterlambatan pengiriman total lokasi proyek.

d. Gambar dan spesifikasi salah.

e. Keterlambatan detail pekerjaan.

3. Non-excusable delays, sepenuhnya kontraktor yang menjadi penanggung jawab atas keterlambatan, dikarenakan dalam pelaksanaan proyek diperpanjang oleh kontraktor akibatnya melebihi tanggal penyelesaian yang telah ditentukan, Kontraktor menghindari penyebab sebenarnya dari keterlambatan. Oleh karena itu, owner client dapat mengklaim kompensasi uang atas keterlambatan tersebut

Beberapa peneliti yang mengkaji tentang penerapan manajemen waktu pada proyek antara lain Analisis Manajemen Waktu Pada Pekerjaan Pembangunan Gedung Lantai 3 Komite Medik, metode penelitian ini dilakukan dengan menyebarkan kuesioner dan wawancara kepada pihak kontraktor, berdasarkan hasil penelitian kendala-kendala yang dihadapi adalah pada masalah monitoring, analysis dan correction action [3]. Faktor-faktor yang mempengaruhi keterlambatan proyek konstruksi di Surabaya, penelitian ini menggunakan metode observasi, wawancara dan kuesioner, berdasarkan hasil penelitian ada 11 faktor yang mempengaruhi keterlambatan proyek, sedangkan faktor dominan ada 5 yaitu perubahan desain oleh pemilik, keterlambatan pengiriman material, keterlambatan pembayaran pekerja, sistem pembayaran yang tidak sesuai kontrak dengan alasan tertentu [4]. Analisa Penerapan Manajemen Waktu Pada Proyek Konstruksi Jalan Lingkungan. Penelitian ini menggunakan metode deskriptif-kualitatif, dari penelitian ini disimpulkan bahwa manajemen waktu yang dilakukan oleh perusahaan kontraktor belum mampu dilaksanakan dengan optimal dikarenakan kurangnya kesadaran pekerja mencatat hasil pekerjaan yang sudah dilakukan, serta tidak teraturnya pemakaian terhadap sumber daya [5]. Analisis Penerapan Manajemen Waktu pada Proyek Bangunan Perkantoran Revistar 3 Lantai Graha Dewata Malang. Penelitian ini menggunakan metode Observasi dan wawancara, hasil dari penelitian ini yaitu pelaksanaan penerapan manajemen waktu pada proyek ini cukup baik, Adapun masalah yang timbul dalam update schedule adalah merubah master schedule dan tanggal penyelesaian proyek apabila adanya kesulitan perubahan milestone [6]. Faktor-faktor Penyebab Keterlambatan pada Proyek Konstruksi dan Alternatif Penyelesaiannya. Penelitian ini menggunakan metode rangking dengan cara menyebarkan kuesioner, dari hasil penelitian faktor yang menjadi penyebab utama yang mempengaruhi keterlambatan penyelesaian yaitu kekurangan bahan konstruksi [7]. Analisis Penerapan Manajemen Waktu pada Rencana Proyek Pembangunan Gedung Cobalt dan Linac RSMH Palembang dengan Menggunakan Metode CPM, hasil dari penelitian ini, direncanakan hanya akan memakan waktu 135 hari. Namun dengan menggunakan diagram alir waktu minimal yang bisa dilakukan yaitu 119 hari [8]. Evaluasi penjadwalan Proyek Pengembangan Rumah Sakit Mitra Husada Pringsewu, hasil penelitian menunjukan bahwa setelah dilakukan evaluasi menggunakan kurva S, biaya pelaksanaan dapat berkurang hingga $10 \%$ dari biaya realisasi, sedangkan dengan menggunakan metode 
CPM, durasi proyek berkurang dari 448 hari menjadi 360 [9]. Evaluasi Waktu Pelaksanaan Pekerjaan pada Proyek Pembangunan Gedung Bappeda Provinsi Kalimantan Utara Tahap III, Penelitian ini menggunakan metode PERT, dari hasil penelitian menggunakan metode PERT, Proyek Pembangunan paling cepat dapat diselesaikan selama 178 hari dengan kemungkinan 0,001\% paling lambat dapat diselesaikan selama 252 hari dengan kemungkinan 99,997\%, paling mungkin diselesaikan selama 218 hari dengan kemungkinan 50\% [10]. Analisis Penerapan Manajemen Waktu Pada Proyek Jalan di Kabupaten Lamongan, penelitian ini menggunakan metode kuantitatif, penelitian ini dilakukan bertujuan untuk menguji teori penerapan standarisasi manajemen waktu dengan penerapan manajemen waktu CV. Duta Parikesit dalam pelaksanaannya [11]. Analisis Faktor-faktor yang mempengaruhi Keterlambatan Proyek Konstruksi Pembangunan Gedung di Kota Lamongan, penelitian ini menggunakan metode Kuesioner, wawancara dan observasi, sampel yang digunakan adalah simple Random Sampling, uji validasi menggunakan metode internal validity, hasil penelitian diklasifikasikan berdasarkan responden kontraktor dan responden pemilik pekerjaan [12]. Faktor-faktor Penyebab Keterlambatan Penyelesaian Proyek Gedung di Kabupaten Karangasem, penelitian ini menggunakan metode statistik, dari penelitian ini disimpulkan terdapat 7 faktor penyebab keterlambatan penyelesaian proyek gedung dengan nilai persen varian, faktor dominan terjadinya keterlambatan penyelesaian proyek yaitu faktor keterlambatan pembayaran dan shop drawing dengan nilai varian terbesar 22,275\% [13]. Analisa Faktor-faktor Penyebab Keterlambatan Proyek Pembangunan Gedung Uvers, penelitian ini menggunakan metode diagram fishbone sehingga dapat dikategorikan faktor-faktor yang mempengaruhi keterlambatan, salah satu faktor yang paling berpengaruh dalam keterlambatan pembangunan adalah dari segi sumber daya manusia, hal ini dikarenakan banyak tenaga kerja yang tidak memiliki keterampilan yang sesuai dengan pekerjaan yang dilakukan [14]

\section{METODOLOGI}

\section{Bagan Alir}

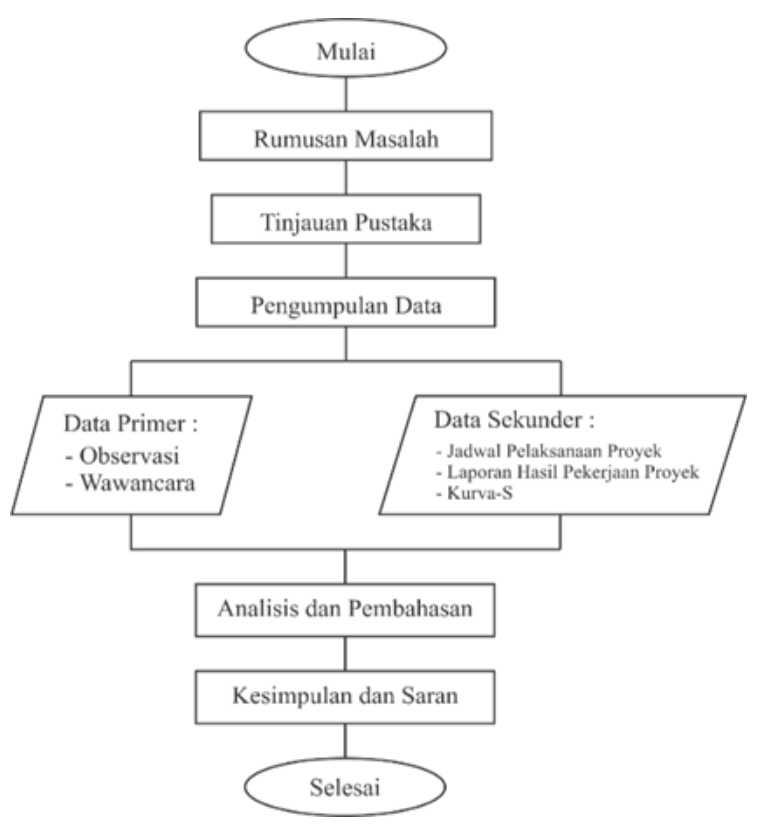

Gambar 1. Bagan Alir Penelitian 


\section{Gambaran Umum dan Lokasi Proyek}

Penelitian ini dilakukan mulai dari tanggal 1 April 2021 sampai tanggal 24 April 2021. pada proyek pembangunan Gedung Ciputra School of Business dalam kawasan Center Point of Indonesia yang lokasinya berada di kota Makassar.

Peta lokasi pembangunan gedung Universitas Ciputra School of Business dapat dilihat pada (Gambar 2).

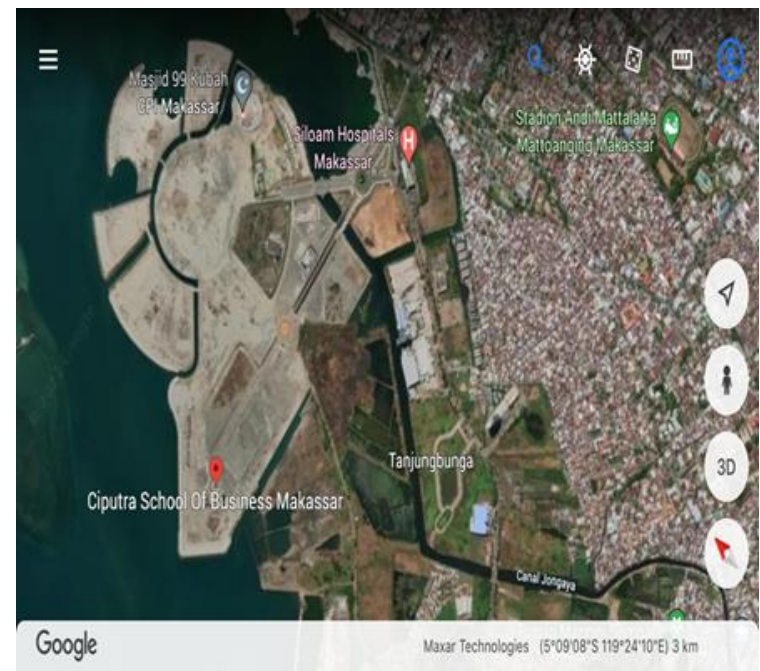

Gambar 2. Lokasi Proyek Penelitian

\section{Pengumpulan Data}

Pengumpulan data dikumpulkan sesuai jenisnya yaitu data primer dan data sekunder, adapun untuk data primer pengumpulan data yang dilakukan berdasarkan hasil wawancara dan observasi lapangan. Sedangkan untuk pengumpulan data sekunder berupa data-data proyek seperti kurva $\mathrm{S}$ dan data penunjang lainnya yang dibutuhkan.

\section{ANALISA DAN PEMBAHASAN}

\section{Data Hasil Wawancara dan Observasi Lapangan}

Wawancara dilakukan pada tanggal 17 April 2021 dengan Chief Engineer PT. X pada proyek pembangunan gedung Ciputra School Of Business. Sedangkan observasi lapangan dilakukan Ketika proyek masih dalam tahap pembangunan, hasil dari wawancara dan observasi lapangan diperoleh sebagai berikut :

\section{a. Penjadwalan Proyek (Schedule)}

Dalam menentukan penjadwalan proyek, PT. X memperhatikan beberapa faktor, antara lain Sumber Daya (alat, tenaga kerja, biaya) dan Kontrak

Dalam penerapan manajemen waktu, pada dasarnya baik dan tidak terlalu menyimpang. Hanya saja yang perlu diperhatikan adalah kemampuan pada para pekerjanya dan ketersediaan material, apakah pekerjaanya bekerja memiliki keterampilan yang baik sehingga bekerja sesuai dengan kapasitas harian yang direncanakan, juga ketersediaan material apakah material yang dipesan stoknya masih ada atau material yang dipesan datang sesuai dengan jadwal. Perlu juga diperhatikan adalah urutan pekerjaan pada Site, sebab ada beberapa jenis pekerjaan yang dapat dilaksanakan secara paralel atau bersamaan, dan pastinya pekerjaan tidak menumpuk dan dapat menghemat waktu pelaksanaan proyek. 


\section{b. Monitoring}

Monitoring yang dilakukan oleh PT. X dilakukan setiap hari setelah proyek mulai berjalan. Aspek yang diamati dalam monitoring meliputi mutu setiap item pekerjaan, dan target waktu yang ditetapkan sesuai dengan jadwal yang direncanakan, kemudian hasil monitoring yang diperoleh setiap harinya dicatat menjadi sebuah laporan mingguan dan bulanan berupa kemajuan fisik proyek sebagai bahan untuk dilakukan evaluasi.

\section{c. Corrective Action}

Hambatan yang ditemui selama proses pembangunan yang mengakibatkan terlambatnya pekerjaan adalah akibat cuaca buruk, keterlambatan material yang didatangkan dari pulau jawa sehingga pihak PT. X melakukan Corrective Action dengan merencanakan ulang penjadwalan pekerjaan untuk melakukan percepatan waktu pekerjaan. Hanya saja ada beberapa item yang harus menunggu kepastian spesifikasi dari pihak Owner. Beberapa item pekerjaan tersebut berupa bahan plafon, keramik, cubicle toilet, sanitary, pintu kayu, aluminium fasad, bata ringan. Dari seluruh item tersebut, yang paling berpengaruh terhadap keterlambatan proyek ialah pintu aluminium, aluminium fasad, pintu kayu sehingga pekerjaan untuk sementara ditunda

\section{d. Update Schedule}

Dikarenakan ketersediaan bahan baku item tertentu menyebabkan waktu pelaksanaan menjadi lebih lama maka diperlukan update schedule.

Pembahasan Analisa Pengendalian Progres Waktu Proyek Dengan Kurva-S

a. Analisa Pengendalian Progres Waktu 3 Bulan Tahap Pertama

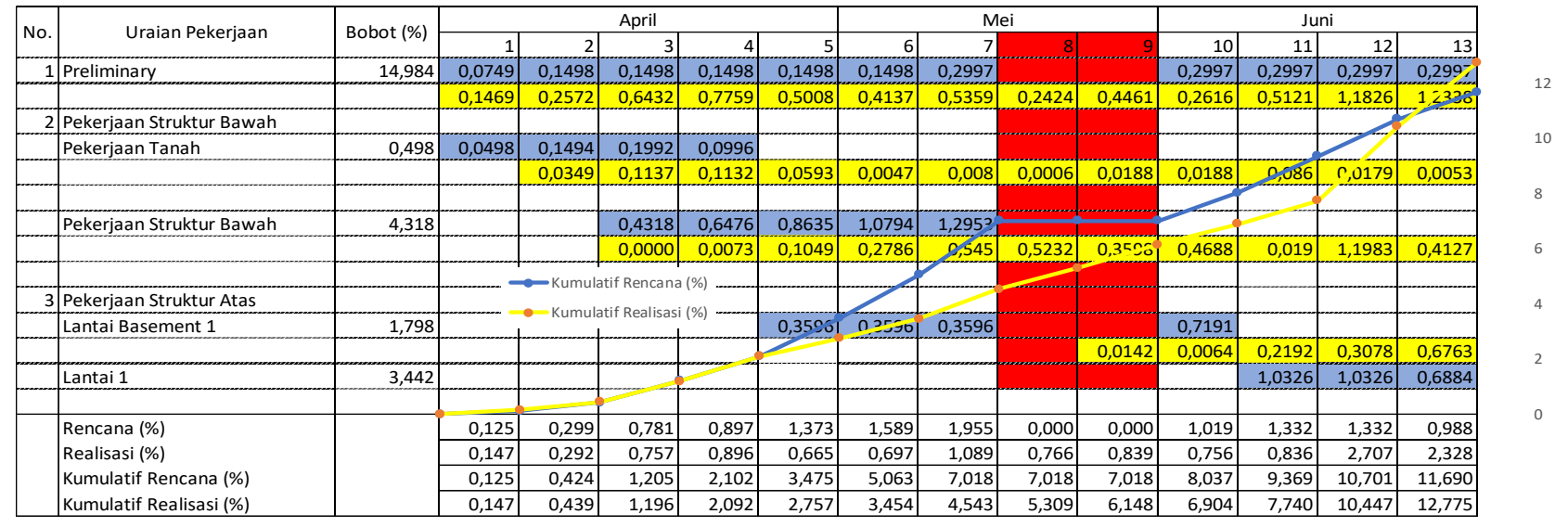

Keterangan: $=$ Libur Lebaran

Gambar 3. Kurva-S 3 Bulan Berjalan

Hasil data aktual lapangan didapat bobot prestasi tiap minggunya, seperti terlihat pada gambar 3 di atas, dimana baseline diambil pertiga bulan dari minggu ke-1 hingga minggu ke-13 adalah: 0,147\%; 0,292\%; $0,757 \% ; 0,896 \% ; 0,665 \% ; 1,089 \% ; 0,766 \% ; 0,839 \% ; 0,756 \% ; 0,836 \% ; 2,707 \% ; 2,328 \%$ yang kesemuanya dikumulatifkan selama 3 bulan ini menjadi $12,775 \%$ sedangkan kumulatif rencana selama tiga bulan 11,690\%. Sehingga diperoleh besaran deviasi yang terjadi adalah sebesar 1.085\%.

b. Analisa Pengendalian Progres Waktu 3 Bulan Tahap kedua 


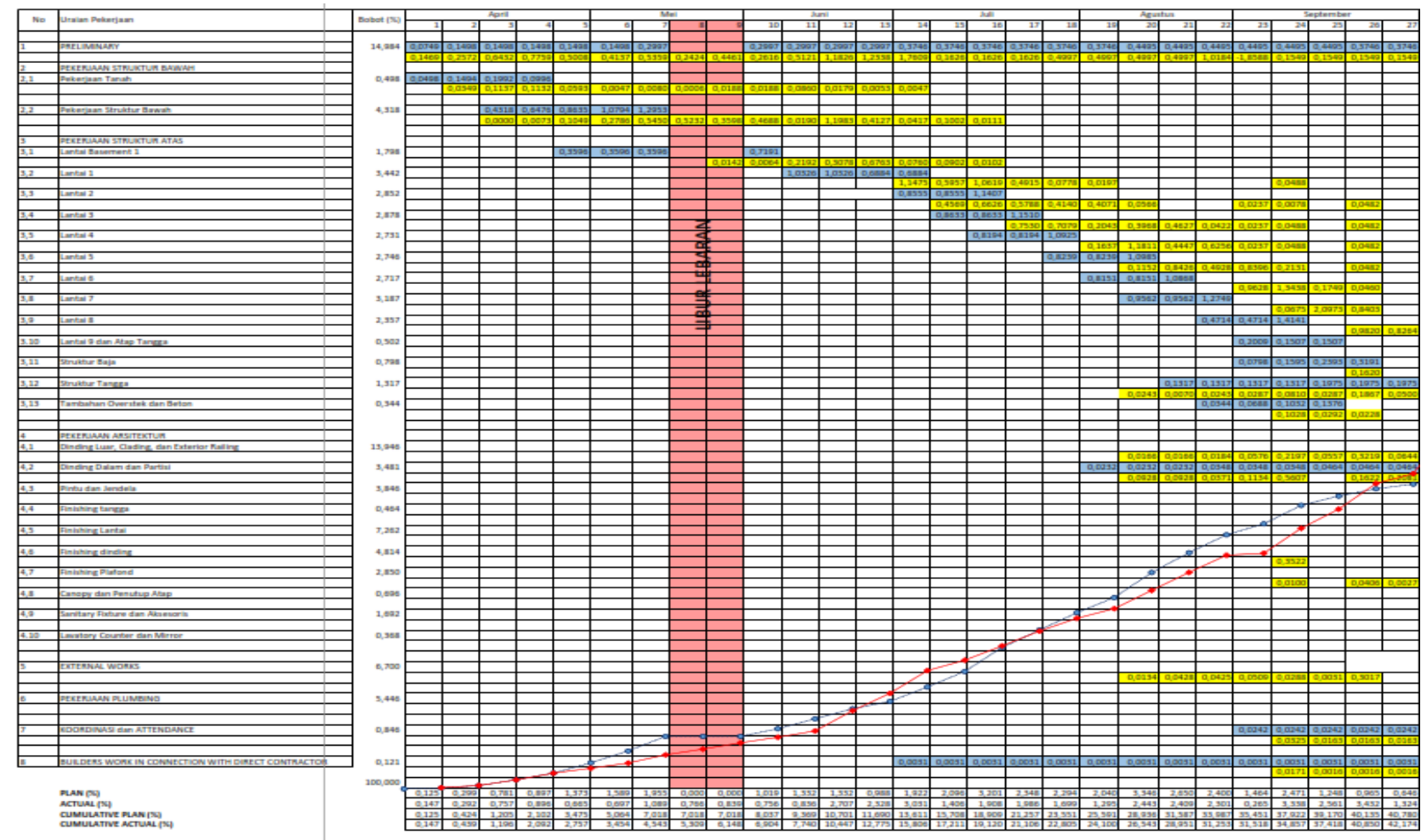

Gambar 4. Kurva S-6 Bulan Berjalan

Hasil data aktual lapangan didapat bobot prestasi tiap minggunya, seperti terlihat pada gambar 4. di atas, dimana baseline diambil pertiga bulan dari minggu ke-14 hingga minggu ke-27 adalah: 3,031\%; 1,406\%; $1,908 \% ; 1,986 \% ; 1,699 \% ; 1,295 \% ; 2,443 \% ; 2,409 \% ; 2,301 \% ; 0,265 \% ; 3,338 \% ; 2,561 \% ; 3,432 \% ; 1,324 \%$ yang kesemuanya dikumulatifkan selama 6 bulan ini menjadi 42,174\% sedangkan kumulatif rencana selama 6 bulan 40,850\%. Sehingga diperoleh besaran deviasi yang terjadi adalah sebesar $1.324 \%$.

\section{c. Analisa Pengendalian Progres Waktu 3 Bulan Tahap ketiga}

Hasil data aktual lapangan didapat bobot prestasi tiap minggunya, seperti terlihat pada gambar 5. di atas, dimana baseline diambil pertiga bulan dari minggu ke-28 hingga minggu ke-40 adalah: 6,438\%; 1,045\%; $0,836 \% ; 0,753 \% ; 0,473 \% ; 0,998 \% ; 1,107 \% ; 2,646 \% ; 2,283 \% ; 4,899 \% ; 6,689 \% ; 7,377 \% ; 1,778 \%$ yang kesemuanya dikumulatifkan selama 9 bulan ini menjadi 79,495\% sedangkan kumulatif rencana selama 9 bulan $88,466 \%$. Sehingga diperoleh besaran deviasi yang terjadi adalah sebesar $-8,971 \%$. 


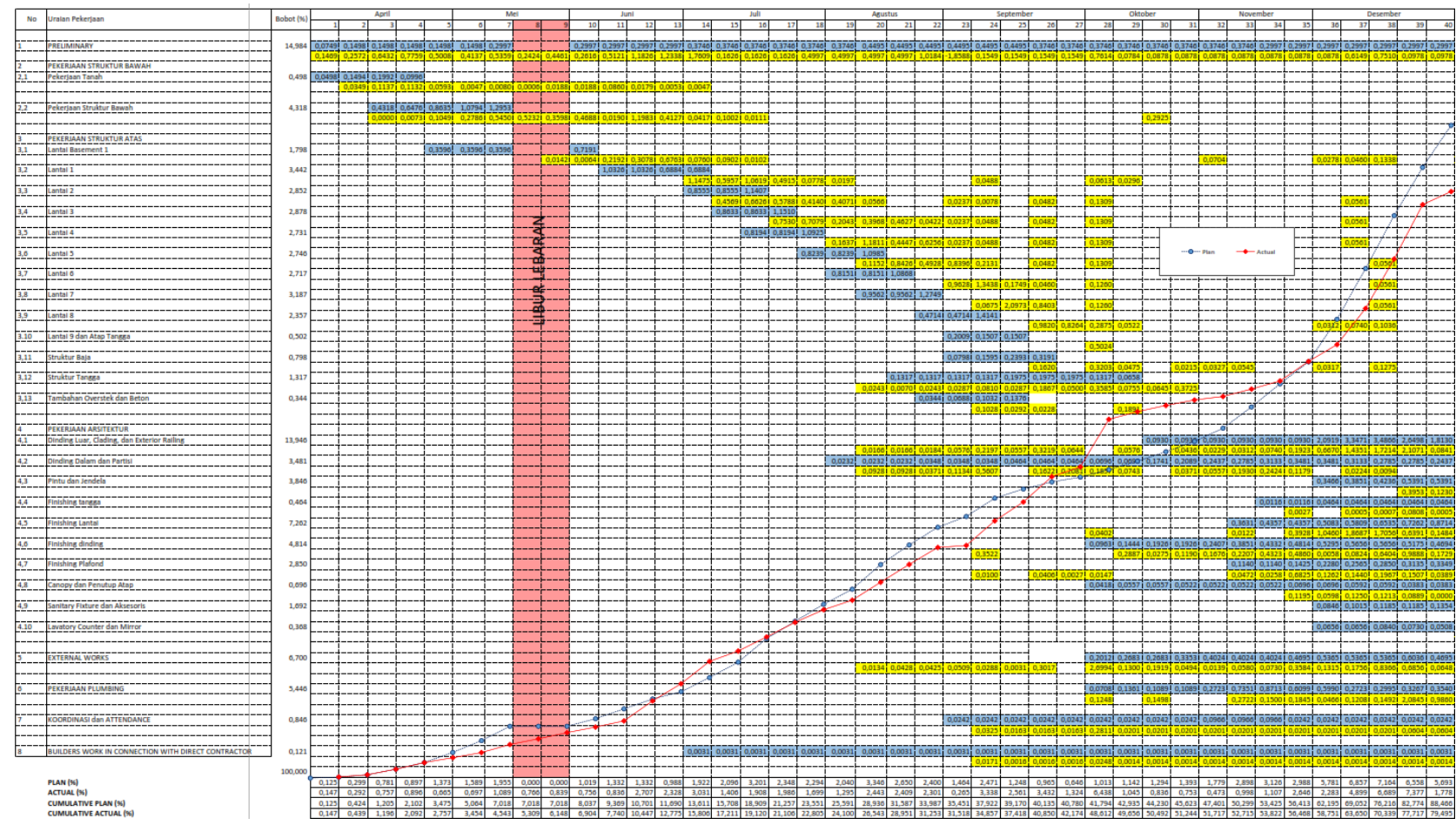

Gambar 5 Kurva-S 9 Bulan Berjalan

d. Analisis Pengendalian Progres Waktu 3 bulan Tahap Keempat

Hasil data aktual lapangan didapat bobot prestasi tiap minggunya, seperti terlihat pada gambar 6 , dimana baseline diambil pertiga bulan dari minggu ke-41 hingga minggu ke-51 adalah: 1,610\%; 0,432\%; 0,589\%; $0,380 \% ; 2,991 \% ; 3,537 \% ; 2,217 \% ; 0,883 \% ; 1,033 \% ; 0,333 \% ; 0,771 \%$; yang semuanya dikumulatifkan selama 12 bulan ini menjadi 94,269\% sedangkan kumulatif rencana selama 12 bulan 99,904\%. Sehingga diperoleh besaran deviasi yang terjadi adalah sebesar $-5,639 \%$. 


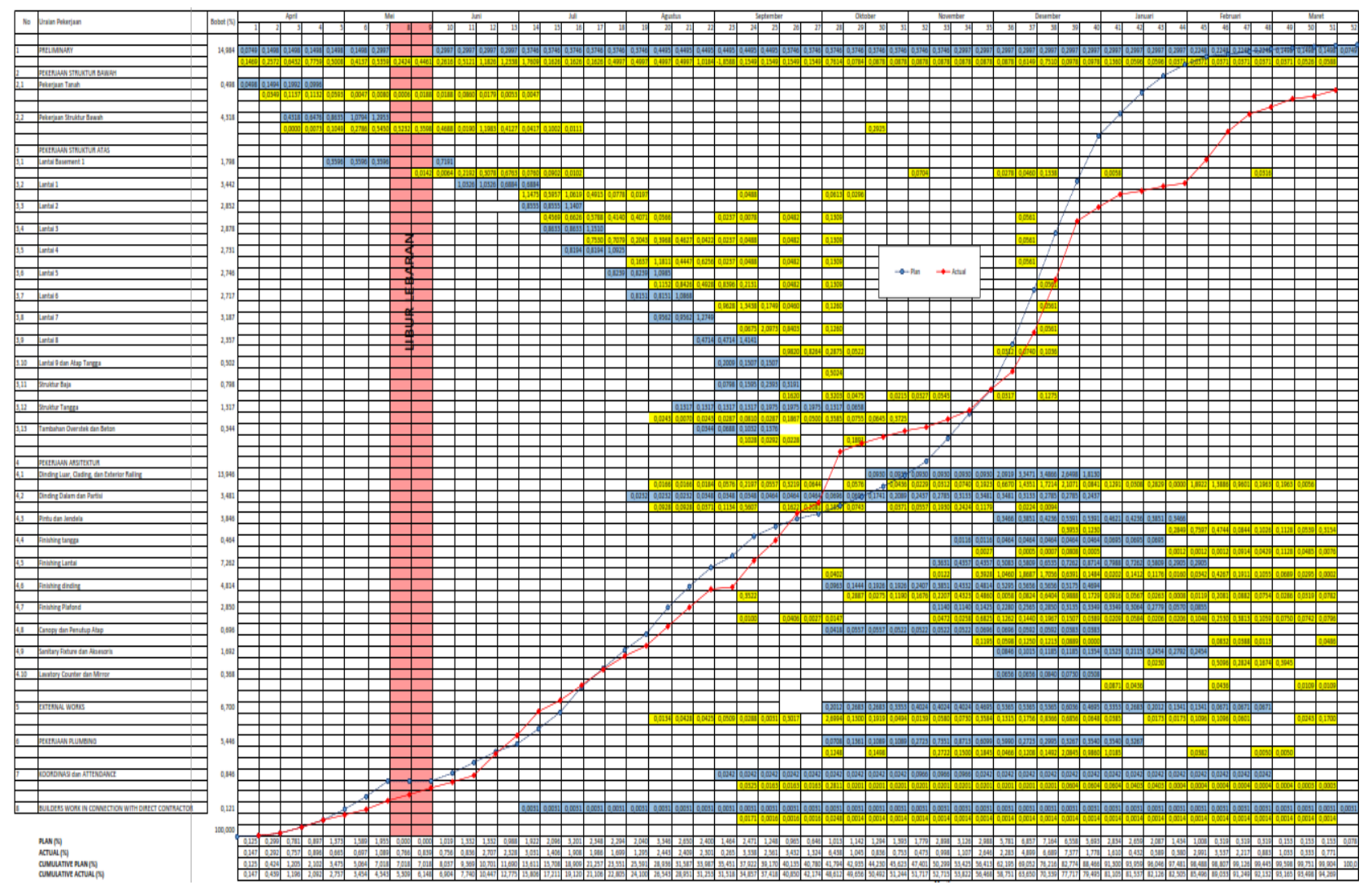

Gambar 6. Kurva-S 12 Bulan berjalan

\section{KESIMPULAN}

Berdasarkan dari hasil evaluasi pada penerapan manajemen waktu proyek pembangunan. Gedung Ciputra School of Business maka dapat disimpulkan bahwa Pihak Kontraktor kurang baik dalam menerapkan aspek-aspek manajemen waktu. sehingga menyebabkan pelaksanaan pekerjaan terlambat. Dapat dilihat dari progress prestasi pekerjaan yang mengalami keterlambatan progress prestasi yang ditetapkan dalam time schedule, yaitu pada bulan kesembilan persentase deviasi sebesar $-8,971 \%$. \% dan pada bulan dua belas sebesar $-5,639 \%$. Adapun solusi yang dilakukan oleh pihak kontraktor yaitu melakukan percepatan dengan memberlakukan sistem kerja paralel atau fast tracking, dan memberlakukan lembur.

\section{DAFTAR PUSTAKA}

[1] A. Husen, Manajemen Proyek, Yogyakarta: Penerbit ANDI, 2011.

[2] PT. PP, Buku Referensi Untuk Kontraktor Bangunan Gedung dan Sipil, Jakarta: Gramedia, 2003.

[3] R. Khoderi dan A. K. Garside, "Analisis Manajemen Waktu Pada Pekerjaan Pembangunan Gedung Lantai 3 Komite Medik," Seminar Keinsinyuran 2021, vol. 1, no. 1, pp. 118-129, 2021.

[4] R. P. Agritama, M. Huda dan T. S. Rini, "Faktor-faktor Yang Mempengaruhi Keterlambatan Proyek Konstruksi di Surabaya," Jurnal Rekayasa dan Manajemen Konstruksi, vol. 6, no. 1, pp. 25-32, 2018.

[5] B. Mochtar, "Analisa Penerapan Manajemen Waktu Pada Proyek Konstruksi Jalan Lingkungan," Jurnal Keilmuan Teknik Sipil, vol. 2, no. 1, pp. 44-52, 2019.

[6] M. Y. Rhebi, N. Rasidi dan S. Suhudi, "Analisa Penerapan Waktu Pada Proyek Bangunan Perkantoran Revistar 3 Lantai Graha Dewata Malang,” Jurnal Penelitian Teknik Sipil dan Teknik Kimia, vol. 1, no. 2, 2017. 
[7] H. Hassan, "Faktor-Faktor Penyebab Keterlambatan Pada Proyek Konstruksi dan Alternatif Penyelesaiannya (Studi Kasus : Di Manado Town Square III)," Jurnal Sipil Statik, vol. 4, no. 11, pp. 657-664, 2016.

[8] D. N. Rachman dan Iswendra, "Analisis Penerapan Manajemen Waktu Pada Rencana Proyek Pembangunan Gedung Cobalt dan Linac RSMH Palembang Dengan Menggunakan Metode CPM," Jurnal Teknik Sipil UNPAL, vol. 8, no. 2, pp. 81-91, 2018.

[9] W. I. Dharnawan, D. Oktarina dan T. C. Wibowo, "Evaluasi Penjadwalan Proyek Pembangunan Rumah Sakit Mitra Husada Pringsewu," Media Komunikasi Teknik Sipil, vol. 23, no. 1, pp. 59-68, 2017.

[10] S. Rantesalu, "Evaluasi Waktu Pelaksanaan Pekerjaan Pada Proyek Pembangunan Gedung Bappeda Provinsi Kalimantan Utara Tahap III," Jurnal Sipil Politeknik, vol. 21, no. 1, pp. 42-46, 2019.

[11] I. Cipta, “Analisis Penerapan Manajemen Waktu Pada Proyek Jalan Di Kabupaten Lamongan,” Journal of Civil Engineering, Building and Transportation, vol. 4, no. 2, pp. 52-56, 2020.

[12] A. Bakhtiyar, A. Soehardjono dan M. H. Hasyim, "Analisis Faktor-faktor Yang Mempengaruhi Keterlambatan Proyek Konstruksi Pembangunan Gedung di Kota Lamongan,” Jurnal Rekayasa Sipil, vol. 6, no. 1, pp. 55-66, 2012.

[13] A. D. P. Dewi, M. Nadiasa dan P. E. E. Savitri, "Faktor-faktor Penyebab Keterlambatan Penyelesaian Proyek Gedung di Kabupaten Karangasem," Jurnal Ilmiah Teknik Sipil - A scientific Journal Of Civil Engineering, vol. 23, no. 1, pp. 79-87, 2019.

[14] F. D. Hanggara, “Analisa Faktor-faktor Penyebab Keterlambatan Proyek Pembangunan Gedung Uvers,” Jurnal Sains dan Teknologi, vol. 20, no. 2, pp. 147-153, 2020.

[15] I. Widiasanti dan L. , Manajemen Konstruksi, Bandung: PT Remaja Rosdakarya, 2013.

[16] H. Kerzner, Project Management (Twelfth Edition), Canada: Wiley, 2017.

[17] M. Pastiarsa, Menyusun Estimasi Biaya Proyek, Yogyakarta: TEKNOSAIN, 2015.

[18] A. N. S. (ANSI), A Guide To The PMBOK Sixth Edition, Pennsylvania: Project Management Institute, Inc., 2017. 